\title{
Teacher Interaction and Academic Freedom of University Students Learning: A Correlation Study
}

\author{
Saghir Ahmad \\ PhD Scholar, Lecturer (Visiting), Institute of Education and Research, \\ University of the Punjab, Lahore Pakistan \\ Dr. Ayesha Batool \\ Lecturer (Visiting), Institute of Education and Research, \\ University of the Punjab, Lahore Pakistan
}

\begin{abstract}
Classroom is the foremost important place in any institution and teacher plays vital role in learning activities. Teacher interacts with students in the learning settings. Students learn more and actively in such kind of environment, where they have academic freedom. This study was designed to investigate the relationship between teacher interaction and academic freedom of student learning at university level. The study was correlational and survey type in nature. The population of the study consisted of different programs of Institution of Education and Research. A sample of 200 students were selected randomly. A five point likert type scale was developed regarding teacher interaction and academic freedom of students learning. Pilot testing was ensured to validate and check the internal consistency of the instrument. Data were collected personally after validation of the scale. There was strong positive relationship between teacher interaction and academic freedom of students learning. In addition, there was no significant difference in perceptions of male and female students regarding teacher interaction but they had different opinions about academic freedom in their learning. University teachers need to develop positive interaction with learners and provide them academic freedom in their learning.
\end{abstract}

Keywords: Teacher interaction, academic freedom, students learning, and environment.

DOI: $10.7176 / \mathrm{DCS} / 9-6-04$

Publication date:June $30^{\text {th }} 2019$

\section{Introduction}

A good and supportive relationship is needed to create safe environments and give students confidence to work without pressure and become motivated to learn. Specifically, when students are exposed to positive emotional stimuli, they are better able to recall newly learned information. Students feel motivated and stimulated to learn and actively collaborate with the teachers when the classroom is running in a safe and supportive environment. Thus, the teacher's role is vital to the effect of the students learning (Nielson, 2014).

As indicated by Davis (2003), it is critical to have a mentor who thinks about their students' needs and qualities, and who holds a steady association with learners, provide them opportunities to take part in the discussion and learning procedure. These open doors make students feel good and allowed to associate in the homeroom and improve their scholarly abilities. An instructor who thinks about their learners transmits learning effectively and has a decent cooperation with them. Furthermore he/she additionally gives to them chance to make an enthusiastic connection. The methods for correspondence of the educator with his/her students in the class is known as instructor relationship. This association incorporates educator authority, companionship and accommodating, getting severity and disappointed (Tsai, 2017).

Rochford (2013) proposed that improving the nature of student teacher collaborations inside the study hall relies on a strong comprehension of the idea of successful educating for young people. The passionate connection makes the students feel good before the instructor and class, which is basic the learners' prosperity and success. Classroom management is the manner in which educators deal the classrooms so as to accomplish desired objectives, as a matter of first importance study hall objectives, which incorporates the manner in which that instructors physically designed the study hall for learning. Instructional backings are essential to assist instructors with providing the best systems, bolster which will better assistance them to separate guidance and address every one of students' needs and encourage their commitment in the learning procedure.

Learners' success or failure can be legitimately connected or credited to an educator's adequacy and how the individual leads and deals with his or her classroom and how the person conveys and persuades students to learn. At the point when learners have strong associations with their educator, they feel more inspiration and occupied with the learning procedure. Scholastic freedom is an opportunity wherein teacher behave friendly with students while teaching and they learn and gain information without impedances or confinements. A student academic freedom as student's entitlement to enjoy freedom of expression and to take an interest in social and political activities. Therefore, it is the students fundamental right to share their feelings, ideas and choose the filed in academic world according to the nature (Karran, 2017). 
Freedom in teaching and learning without impedance is the privilege of teachers and students. The presumption that teachers ought to have the option to instruct and lead research and students ought to able to study without hurdles and impedance has been characterized as academic freedom. The meaning of academic freedom is different in different contexts based on historical periods and specific academic institutions. Altbach (2001) specified that academic freedom appears a straightforward idea, and fundamentally it is, however it is likewise hard to define. From medieval occasions, scholastic freedom has implied the freedom of the teachers to instruct and teach without outside control in specialized topic, and it has suggested the freedom of the students to learn. The function of academic freedom is to advance learning, its improvement in research, and its protection and basic transmission in instructing. This perspective demonstrates that scholarly freedom is not the freedom to do whatever a teacher wishes to do. It does not give the free hand to teachers to state anything in the classroom. It is attached to the obligation and connected to the objectives of the institution. The significance of scholarly freedom is seen in connection to the elements of academic organizations (Castells, 2001).

To achieve the desired and set goals, academic institutions need to introduce the concept of academic freedom for teachers and students. Altbach (2001) clarified that scholastic freedom is the core mission of the schools. The significance of academic freedom as the cornerstone of the organization's mission to teach learners and extend the limits of information and knowledge. In such manner, staff and students, who are the significant part of this process, need scholastic freedom to accomplish their objectives without outside and inward impedances (Streb, 2006). The nature of student teacher relationship in the classroom is progressively recognized as of significant factor for learner achievement in school. Current studies has uncovered that learner learning results improve when they go to study halls in which the instructors are warm and react to student needs, provide healthy atmosphere to students in the classroom. As well as monitor and provide feedback to students on their work.

Alstyne (2000) further explains that: Academic freedom is characterized by a personal liberty to pursue the investigation, research, teaching and publication of any subject matter of professional interest without vocational jeopardy or threat of other sanction, save only upon adequate demonstration of an inexcusable breach of professional ethics in the exercise of that freedom. This point of view also suggests that academic freedom is to protect the rights of academics to conduct academic actions without any control. However, these rights are concerned with professional ethics. In addition to these rights, Academic freedom is also the freedom of academic individuals to involve different activities within the university.

Academic freedom is also important for the completion of the mission of a university. As Down (2009) claimed that the future of the university depends on a healthy climate for academic freedom. He further explained that "academic freedom is a fundamental prerequisite for an effective university and a core value for academia universities cannot achieve their potential nor fully contribute to the emerging knowledge-based society without academic freedom. In this context, academic freedom is the fundamental principle for the university enables it to contribute for the production and application of knowledge. Academic freedom is an important subject and is related to the effective leaning of student. Students therefore, face difficulties in learning and have fewer opportunities for academic freedom or less teacher interaction. Consequently, student learning always remains low through less teacher interaction. The teacher is a change agent who can not only help the student in improving their learning but also change the student attitude.

\section{Significance of Study}

This study has both theoretical and practical significance. The relationship between teacher interaction and academic freedom of students learning provides valuable information regarding attitudes towards learning. The result of this study may be beneficial for teachers in improving their teaching and classroom interaction. Assessing classroom psychosocial environment would contribute worthwhile information that is useful in enhancing student's attitudes towards teacher interaction and academic freedom in student learning. The findings may assist teachers in identifying features to contribute towards creating a positive learning environment.

\section{Research Objectives}

The current study was conducted to pursue the following objectives;

1. Explore relationship between teacher interaction and academic freedom of students learning.

2. Identify the difference between male and female students' perceptions regarding teacher interaction and academic freedom of students learning.

\section{Research Methodology}

Quantitative research was conducted and correlation design was employed. This study was accomplished to explore the relationship between student teacher interaction and academic freedom on students learning. The accessible population of the study was included Institute of Education and Research, University of the Punjab. 
The population of the study spread over the eight programs from IER. The participants selected randomly from different departments of institution. The sample consisted of two hundred students.

Questionnaire was developed by the researchers to conduct this study. The scale regarding teachers' interaction and academic freedom of students learning was constructed. The Questionnaire consisted of thirty nine items, consisted of two independent variables (teacher interaction and academic freedom). There was five factors of teacher interaction were teacher leadership, friendly and helpful, understanding, dissatisfaction and strictness. The other variable academic freedom consisted of three factors rights, climate, and institutional freedom. Personal information of the students like locality, age, gender, and programs were asked.

These items were rated on five-point Likert-type scales (from strongly agree to strongly disagree). The validity and reliability of the scale (teacher interaction and academic freedom) was confirmed. Validity of the instrument was ensured by relevant field experts. Internal consistency of scale was measured by Cronbach's alpha for confirming reliability. Data collected and analyzed with the help of statistical package for social sciences. Different statistical techniques were applied to analyze the data. Descriptive (frequency, mean, and standard deviations) and inferential statistical techniques (Pearson r, independent sample t-test, and one way Anova) were used.

\section{Data Analysis}

This section deals with data analysis.

Table 1

Reliability to Check Internal Consistency of Sub-Factors and Factors of Scale

\begin{tabular}{lcc}
\hline Factors & Items & Alpha Coefficient \\
\hline Teacher leadership & 5 & 0.733 \\
Friendly and helpful & 5 & 0.772 \\
Understanding & 5 & 0.792 \\
Dissatisfaction & 5 & 0.769 \\
Strictness & 5 & 0.797 \\
Rights & 5 & 0.785 \\
Climate & 5 & 0.781 \\
Institutional freedom & 4 & 0.829 \\
Teacher Interaction & 25 & 0.927 \\
Academic Freedom & 14 & 0.905 \\
\hline
\end{tabular}

Table 2

Gender Distribution of the Sample

\begin{tabular}{ccc}
\hline Gender & $N$ & Percentage \\
\hline Male & 28 & 14 \\
Female & 172 & 86 \\
Total & 200 & 100 \\
\hline
\end{tabular}

Table demonstrates the gender distribution of the sample of the study. There were 28 male and female 172 students. Total 200 students were participated in the study.

Table 3

Correlation between Teacher Interaction in Classroom and Students Academic Freedom

\begin{tabular}{lcc}
\hline Variable & $r$ & $P$ \\
\hline Teacher Interaction and Academic freedom & .772 & .000 \\
\hline
\end{tabular}

Table shows the relationship between students' perception about teacher interaction in classroom and academic freedom. The results revealed that there was significant positive strong relationship between teacher interaction in classroom and academic freedom $(r=.772, p<.05)$. It is concluded that teachers interaction influences positively of academic freedom in the classroom.

Table 4

Correlation between Teacher Interaction in Classroom and Students Learning

\begin{tabular}{lcc}
\hline Variable & $r$ & $P$ \\
\hline Teacher Interaction and Student learning & .164 & .021 \\
\hline
\end{tabular}

Table shows the between students' perception about teacher interaction and students learning. The results revealed that there was weak significant relationship between teacher interaction in and students learning ( $r$ $=.164, p<.05)$. It is concluded that there is significant weak relationship between teacher interaction and students learning. 
Table 5

Relationship between Academic Freedom and Students Learning

Variable

Academic freedom and Student learning

.052

Table shows the between students' perception about academic freedom and students learning. The results revealed that there was no significant relationship between academic freedom and students learning $(r=.052$, $p>.05)$. It is concluded that there is no significant relationship between academic freedom and students' learning.

Table 6

Independent Sample t-test to Check Gender Difference Regarding Factors (Teacher Interaction and Academic Freedom) and Sub-Factors

\begin{tabular}{|c|c|c|c|c|c|c|c|}
\hline Factors & Gender & $N$ & Mean & $S D$ & $t$-value & $d f$ & $p$ \\
\hline \multirow[t]{2}{*}{ Teacher Leadership } & Male & 28 & 19.89 & 3.178 & 2.043 & 198 & $.042 *$ \\
\hline & Female & 172 & 18.48 & 3.436 & & & \\
\hline \multirow[t]{2}{*}{ Friendly Helpful } & Male & 28 & 20.71 & 3.640 & 1.935 & 198 & .054 \\
\hline & Female & 172 & 19.28 & 3.639 & & & \\
\hline \multirow[t]{2}{*}{ Understanding } & Male & 28 & 19.64 & 3.946 & .815 & 198 & .416 \\
\hline & Female & 172 & 19.02 & 3.693 & & & \\
\hline \multirow[t]{2}{*}{ Dissatisfaction } & Male & 28 & 18.82 & 3.954 & .129 & 198 & .897 \\
\hline & Female & 172 & 18.73 & 3.539 & & & \\
\hline \multirow[t]{2}{*}{ Strictness } & Male & 28 & 21.11 & 2.973 & 1.569 & 198 & .118 \\
\hline & Female & 172 & 20.05 & 3.368 & & & \\
\hline \multirow[t]{2}{*}{ Teacher Interaction } & Male & 28 & 100.18 & 14.777 & 1.543 & 198 & .124 \\
\hline & Female & 172 & 95.55 & 14.697 & & & \\
\hline \multirow[t]{2}{*}{ Rights } & Male & 28 & 21.07 & 2.775 & 1.725 & 198 & .086 \\
\hline & Female & 172 & 19.88 & 3.466 & & & \\
\hline \multirow[t]{2}{*}{ Climate } & Male & 28 & 21.50 & 2.887 & 2.577 & 198 & $.011 *$ \\
\hline & Female & 172 & 19.64 & 3.635 & & & \\
\hline \multirow[t]{2}{*}{ Institutional Freedom } & Male & 28 & 16.68 & 3.762 & 1.300 & 198 & .195 \\
\hline & Female & 172 & 15.78 & 3.308 & & & \\
\hline \multirow[t]{2}{*}{ Academic Freedom } & Male & 28 & 59.25 & 7.816 & 2.125 & 198 & $.035^{*}$ \\
\hline & Female & 172 & 55.31 & 9.291 & & & \\
\hline
\end{tabular}

Table shows the t-test results on the basis of gender of students. The p-value is significant at alpha $<.05$. The male students perceived higher than female students regarding teacher leadership, Climate and academic freedom factors. However the results suggest that students perceived equally towards remaining factors for example friendly, understanding, dissatisfaction, strictness, teacher interaction, rights and institutional freedom as the $\mathrm{p}$-values are not significant at alpha $<.05$ level of significance.

\section{Discussion}

The major objective of research is to explore the relationship between teacher interaction and academic freedom of student learning. According to Caston (2006) caring facilitates a sense of connection from which spring countless opportunities for learning. Teachers and students were surveyed about the use of CLT approach in classroom. They show a particular interest in this approach because they feel that it is more useful and very helpful for students. CLT is seen as an approach which provides opportunities for students to communicate and interact with their colleagues and teachers in class. They have academic freedom in their learnings (Nordal, 2016).

According to Hogan (2013), findings from the surveys show that the majority of teachers and students value a supportive and caring relationship between them and that interaction is essential to the teacher-student relationship. This sense of caring and supporting from teachers motivates students to become a more interested learner. A caring teacher will help students to overcome struggles. These results are align with findings of current study that teacher interaction and academic freedom of students learning have healthy association and promote vigorous environment for better academic achievements. This research explore that students perceive their teacher interaction in terms of teacher leadership, understanding and friendly/helpful behavior and whereas their perception is least positive in terms of dissatisfaction and strictness. Students perceive their academic freedom as almost equity based. Students involved in different aspects of academic freedom like freedom of speech, choosing field, freedom of research, cognitive intellectual freedom etc. under the consideration of teacher interaction. It is found that dissatisfaction and strictness behaviors of teacher interactions are negatively effects the academic freedom. Results of the study showed that scales of teacher interaction are significantly and strongly positive correlated with the students' learnings. 


\section{Conclusion}

The main purpose of the study is to explore the relation of academic freedom and student's perception about teacher interaction. Teachers in classroom holds strong leadership qualities, show great care and understanding for students, assign duties to students and are helping and friendly. They are not dissatisfy, admonishing and uncertain in classroom. Because of teacher interaction students in the classroom are cohesive, involve, initiative and task oriented. Students' show better results where the perception about teacher is helping and friendly also the teachers are not strict or uncertain. Task oriented and equity based classroom environment develops student better learnings. Female students perceive more academic freedom than teacher interaction and male students perceive more teacher interaction than academic freedom as compare to female students. The results revealed that there was significant positive strong relationship between teacher interaction in classroom and academic freedom. It is concluded that teachers interaction influences positively of academic freedom in the classroom. It is concluded that there is significant weak relationship between teacher interaction and students learning but there is no significant relationship between academic freedom and students' learning. The results of different studies from all over the globe are also confirming and supporting the findings of current study.

\section{Recommendations}

Following are some recommendations on the basis of findings.

1. Positive and constructive learning environment may be created by those teachers who possesses the qualities of teacher leadership, friendly/helpful, understanding and assign duties to their students.

2. Teachers may improve their teaching and students' academic freedom by using new interacting leadership theories and practices and avoid uncertainty.

3. Academic freedom means that the university can determine for itself on academic grounds: a. who may teach, b. what may be taught, c. How it shall be taught, d. who must be admitted to study? Therefore, it is the responsibility of the institution to provide the learning environment as well as the plate form of learnings to speech, listen, write and play.

4. There is a need to create or develop positive environment with the characteristic of critical judgment. This result may be due to the fact that the university education plays a vital role in providing students with a good foundation of knowledge for their future profession. There are also an alternative and free choice studies, which can be selected from a diversity of subjects. They can then be fitted into one's studies according to accessibility.

5. This study supports the notion that academic freedom is needed to the university's research activities. An open instructional environment and climate is important for the protection of the rights of faculty to teach and of the students' freedom to learn.

6. Skill development and Education training departments may concentrate and help teachers to attend workshops, seminars and trainings to develop their knowledge and skills for conducive learning environment.

\section{References}

Akker, J. (2006). Academic freedom in the Middle East, Africa, and Asia: Looking toward the near future. Academic freedom at the dawn of a new century: How terrorism, governments and culture wars impact free speech (99-114). California: Stanford University Press

Alstyne, V. (2000). The specific theory of academic freedom and the general issue of civil liberty. William and Mary Law School.

Altbach, P. G. (2001). Academic freedom: International realities and challenges. Higher Education, 41(1/2), 205-219.

Andreescu, L. (2009). Foundations of academic freedom: Making new sense of some aging arguments. Studies in Philosophy and Education, 28(6), 499-515.

Beishuizen, J. (2010). Scaffolding in teacher student interaction: A decade of research. Educational Psychology Review, 22, 271-296.

Berdhal, R. (2010). Thoughts about academic freedom, autonomy and accountability. Published by Sabanci University Istanbul.

Better, K. D. (2016). Academic freedom and its protection in the law of European States measuring an International Human Right. European Journal of Comparative Law and Governance, 3, 254-345.

Castells, M. (2001).Universities as dynamic systems of contradictory functions. Challenges of globalization: South African debates with Manuel Castells (206-224). Cape Town: Maskew Miller Longman.

Caston, G. (2006). Academic freedom: The Third World context. Oxford Review of Education, 15(3), 305-338.

Davis. A. H. (2003). Conceptualizing the role and of student-teacher relationships on children's social and cognitive development. Journal of Educational Psychologist, 38(4), 207-234. 
Downs, D. A. (2009). Academic freedom: What it is, what it isn't and how to tell the difference. Published by The John William Pope Center. Retrieved from http://www.popecenter.org/acrobat/AcademicFreedom.pdf

Hogan, B. E. (2013). Academic freedom in Canadian higher education: Universities, colleges and institutes were not created equal. Canadian Journal of higher Education, 43(2), 68-84.

Karran, T. (2017). Academic freedom: In justification of a universal idea. Journal of Studies in Higher Education, 3(2).

Nielsen, W. (2014). Cooperating teacher participation in teacher education: A Review of the literature. Journal of review of Educational Research. 84(2), 163-202.

Nordal, E. (2016). Students' academic freedom in Europe; A means to an end or an end in itself? Master of Philosophy in Higher Education Department of Education Faculty of Educational Sciences: Reprosentralen, Universities I Oslo.

Rochford, F. (2013). Academic freedom as insubordination: The legislation of the academy. Journal of the Education and the Law, 15(4).

Streb, M. J. (2006). The reemergence of the academic freedom debate. Academic freedom at the dawn of a new century: How terrorism, governments and culture wars impact free speech (3-16). California: Stanford University Press.

Tsai, K. C. (2017). Teacher student relationships, satisfaction, achievement among Art and Design College in Macau. Journal of Education and Practice, 8(6). 